\author{
М.Б. СУШАК ${ }^{1}$, В.М. ГРЕНЬ ${ }^{1}$, Н.В. КЛОБУКОВА ${ }^{1}$, І.О. ЧЕРНОЗУБКІН ${ }^{2}$ \\ ${ }^{1}$ Державний науково-дослідний інститут авіачій, Київ \\ ${ }^{2}$ Центральний науково-дослідний інститут Збройних Сил Украйни
}

\title{
МЕТОДИЧНИЙ ПІДХІД ЩОДО ВИЗНАЧЕННЯ ОСНОВНИХ ПОКАЗНИКІВ НАДІЙНОСТІ ЗРАЗКІВ АВІАЦІЙНОЇ ТЕХНІКИ В МІЖРЕМОНТНИЙ ПЕРІОД ЕКСПЛУАТАЦЇ̈
}

\begin{abstract}
Представлено результати розроблення методичного підходу до визначення основних показників надійності зразків авіаційної техніки (АТ) парку Збройних Сил України, які експлуатуються за межами попередньо встановлених ресурсних показників. Використання запропонованих в статті математичних моделей та методичного підходу до визначення імовірнісних властивостей процесу гарантійного обслуговування зразків AT, які експлуатуються за межами попередньо встановлених ресурсних показників, дають можливість в певній мірі уникнути відмов, які не пов'язані з проведенням ремонту на авіаремонтних підприємствах, а є наслідком конструктивних недоліків, та тривалого терміну експлуатації.
\end{abstract}

Ключові слова: ремонт, гарантійне обслуговування, експлуатація, надійність, ресурсні показники.

\section{Вступ}

Постановка проблеми. Основним напрямом розвитку авіації Збройних Сил України (3С України) на середньострокову перспективу, залишається ремонт та модернізація (у разі доцільності) АТ, що дозволяє забезпечити відповідність ऑiі бойових можливостей вимогам сучасних війн (збройних конфліктів) при обмежених фінансових ресурсах.

Результати аналізу існуючого стану парку AT 3С України показує, що експлуатація значної іiі кількості здійснюється за межами попередньо встановлених ресурсних показників, що зазвичай призводить до ситуації коли відмова, яка виникла в процесі гарантійного обслуговування зразків AT, не пов'язана 3 проведенням ремонту на авіаремонтних підприємствах (АРП), а $\epsilon$ наслідком конструктивних недоліків та тривалого терміну експлуатації, який значно перевищує ресурсні показники, що встановлені розробником.

Як наслідок, у цих обставинах АРП несе незаплановані фінансові витрати на відновлення гарантійного виробу в цілому, в тому числі на відновлення вузлів та деталей виробу, які під час ремонту не замінювались на нові та окремо не ремонтувались, адже це не передбачено (відповідно до вимог існуючої ремонтної документації). Виникає ситуація, коли, у випадку зняття з АРП зобов'язань відновлення справності агрегатів (блоків, виробів), якими був укомплектований основний виріб (літак, вертоліт) після ремонту (не взяття підприємством гарантійних зобов'язань на виріб у цілому), питання відновлення справності автоматично перекладається на замовника робіт, який змушений повторно нести додаткові витрати, вважаючи їх необгрунтованими. Виникає конфлікт інтересів між замовником та виконавцем ремонтних робіт.

Вирішення вищезазначеного проблемного питання полягає у визначенні об'єктивних властивостей процесу гарантійного обслуговування зразків АТ, що експлуатуються за межами попередньо встановлених ресурсних показників, та відповідного нормативноправового врегулювання. Це дозволить усунути невідповідність між існуючими потребами забезпечення заданого рівня справності парку АТ 3С України та реальними (об'єктивними) можливостями АРП щодо гарантійного обслуговування зразків АТ, які експлуатуються за межами попередньо встановлених ресурсних показників [1, с. 8..13].

На певних етапах життєвого циклу експлуатації повітряного судна можливо забезпечувати підтримку характеристик його безвідмовності, ремонтопридатності, довговічності та зберігаємості. На сьогоднішній день актуальним питанням є розробка програми забезпечення надійності АT, в якій має бути встановлено комплекс взаємообумовлених організаційно-технічних вимог та заходів, що спрямовані на забезпечення заданих вимог до надійності при імпортозаміщенні [2, с. 71...79].

Відмови, які виникають на зразках АТ 3С України в післяремонтний період, підпорядковані імовірнісним законам розподілу і мають велике значення для теорії і практики робіт щодо забезпечення надійності виробів. Знання цих 
законів дозволяє розраховувати та прогнозувати надійність виробів на етапах їх гарантійного обслуговування. Особливо велике значення врахування прогнозованих законів розподілу відмов мають при оцінці обгрунтованості встановлення та продовження ресурсу виробів АТ до граничного рівня, адже від цього залежить безпека польотів літальних апаратів (ЛА).

3 великого різноманіття законів розподілу випадкових величин, які розроблені в теорії ймовірностей, найбільш прийнятними для моделювання процесу змінювання показників надійності мають такі закони: біноміальний та Пуассона - для дискретних величин; експоненційний, Вейбулла та нормальний - для безперервних величин. Крім того, використовуються два додаткових закони - “ $\chi-$ квадрат" та " $\gamma$-розподіл“ [3, с. 73]. Для складних та багатофункціональних розподілів використовуються композиції вказаних законів розподілу.

Мета статті - представити результати дослідження авторів при розробці методичного підходу до визначення ймовірнісних властивостей процесу гарантійного обслуговування зразків АТ, які експлуатуються за межами попередньо встановлених ресурсних показників та обгрунтувати напрями подальших досліджень

\section{Виклад основного матеріалу}

Основна сутність кожного 3 вищезазначеного закону розподілу випадкових величин наступна:

1. Біноміальний розподіл.

Біноміальний розподіл використовується для дослідження дискретних випадкових величин (наприклад, числа відмов $m$ ). Цей розподіл може бути отримано, якщо в якості випадкової величини взято число відмов, які виникають в процесі експлуатації однотипних зразків АТ після ремонту в однакових умовах.

Якщо $q$ - ймовірність появи відмови в кожному 3 вильотів $(q=$ const $) ; n$-число вильотів; $m$-можливе число відмов при кількості $n$ польотів ( $m$ може бути цілим числом від 0 до $n$ ), то ймовірність можливих значень випадкової величини $x$, яка розглядається, визначається за формулою Бернуллі:

$$
\begin{aligned}
& P(x=m)=C_{n}^{m} q^{m}(1-q)^{n-m} \text { (1) } \\
& \text { де } \quad m=0,1,2, \ldots, n ; \quad C_{n}^{m}-\quad \text { число всіх }
\end{aligned}
$$

можливих варіантів, які можливо розглянути $3 n$ польотів, в кожному з яких виникає $m$ відмов:

$$
C_{n}^{m}=\frac{n !}{m !(n-m) !}
$$

Розподіл дискретної випадкової величини, що визначається даною формулою, називається біноміальним розподілом.

В якості прикладу практичного використання біноміального розподілу пропонується визначення кількості відмов неремонтуємих виробів АТ протягом заданого часу (часу гарантійного обслуговування після ремонту основного виробу) в процесі їх експлуатації.

При надто малих значеннях $q$ біноміальний розподіл може бути замінено розподілом Пуассона, а при великих значеннях $n q$, тобто при $n q>20,-$ нормальним розподілом.

2. Розподіл Пуассона.

Розподіл Пуассона (закон рідкісних явищ) розповсюджується, як і біноміальний розподіл, на ті випадки, коли випадкова величина приймає цілі та позитивні значення. Фізична сутність розподілу Пуассона така ж сама, як i біноміального розподілу, тобто він визначає ймовірність появи в малих вибірках різних значень випадкової величини кількості відмов $m$.

Ця ймовірність визначається за формулою:

$$
P_{m n}=\frac{1}{m !} a^{m} e^{-a},
$$

де $a=q k ; k$ - число виробів одного типу (кількість виробів АТ у вибірці), що досліджуються; $q$ - ймовірність появи відмови протягом незначного часу експлуатації виробу після ремонту, тобто в період гарантійного обслуговування виробу.

Розподіл Пуассона можливо використовувати наступним чином:

по-перше, як замінник біноміального розподілу в тих випадках, коли діє біноміальний закон, але ймовірність $q \leq 0,1[3$, с. 81].

по-друге, при виконанні ряду розрахунків щодо надійності та при післяремонтній експлуатації виробів АТ, які ремонтуються. При сталих режимах роботи випадкове число відмов розподілене за законом Пуассона (в цьому випадку можливість використання закону Пуассона не залежить від ймовірності $q$ ) [3, с. 85].

Числова рівність математичного очікування $\hat{M}(x) \quad$ та дисперсії $\hat{D}(x)$ зазвичай використовується на практиці для вирішення 
питань та обгрунтування правильності припущень про наявність пуассонівського розподілу випадкових величин, які розглядаються. Для цього 3 досвіду визначаються статистичні характеристики $\hat{M}(x), \hat{D}(x)$ та, якщо їх значення близькі, то це підтверджує правильність припущення щодо наявності розподілу Пуассона [3, с. 91..93].

Розподіл Пуассона при $m=0$ трансформується в суто експоненційний розподіл.

3. Експоненційний розподіл.

Експоненційний закон - це один із основних законів розподілу тривалості строку (ресурсу) служби виробів АТ. Принаймні, за цим законом розподіляється час напрацювання до відмови деяких неремонтуємих виробів АТ при їх роботі на сталих режимах (для раптових відмов, які не пов'язані $з$ процесом зношення та/або старіння).

За основний параметр експоненційного розподілу береться $\lambda(t)$, який характеризує інтенсивність відмов для неремонтуємих та параметр потоку відмов для ремонтуємих виробів AT. Для неремонтуємих виробів $\lambda(t)$ показує, яка частка працюючих в момент часу виробів АТ виходить $з$ ладу в одиницю часу після моменту $t$ (в період гарантійного обслуговування).

Приймаючи в якості випадкової змінної величини час $t$ (наробіток до відмови або між відмовами) та вважаючи $\lambda$ =const, можливо виразити щільність розподілу тривалості строку служби (наробітку) наступною формулою $[3$, c. 101]:

$$
f(t)=\lambda e^{-\lambda t}
$$

де $\lambda=$ const .

Функція експоненційного розподілу визначається з рівняння

$$
F(t)=\int_{0}^{t_{i}} f(t) d t=\int_{0}^{t_{i}} \lambda e^{-\lambda t}=1-e^{-\lambda t_{i}}
$$

Так як $F(t)=1-P(t)$, то основне рівняння надійності буде таким [3]

$$
P(t)=e^{-\lambda t},
$$

Використовуючи

співвідношення $\lambda(t)=\frac{f(t)}{P(t)}, \quad$ можливо вивести ймовірностей безвідмовної роботи $P(t)$ для будьякого закону зміни $\lambda(t)$ від часу:

$$
P(t)=e^{-\int_{0}^{t_{1}} \lambda(t) d t} .
$$

Для випадку $\lambda(t)=$ const отримаємо формулу для експоненційного закону $P=e^{-\lambda t}$.

На практиці часто буває так, що експоненційний закон не має місця $\lambda(t) \neq$ const, але i в цьому випадку його можливо використовувати для обмежених відрізків часу. Це припущення обгрунтовується тим, що, при обмеженому періоді часу змінну інтенсивність відмов без великої похибки можливо замінити середнім значенням $\lambda_{c p}$, тобто $\lambda(t) \sim \lambda_{c p}(t)$.

Визначаючись із вибором математичних моделей закону розподілу випадкових величин, які розроблені в теорії ймовірності, слід мати на увазі, що експоненційний закон доцільно використовувати тільки стосовно виробів АТ, які $\epsilon$ стійкими до процесу старіння та/або зношенню під час роботи, або у яких цей процес проходить дуже повільно. Цей закон, в основному, використовується для розподілу раптових відмов, які випадковим чином виникають при експлуатації АТ в міжремонтний період.

Слід враховувати, що експоненційний розподіл - це єдиний розподіл випадкових величин, де використовується припущення, що, якщо пристрій має експоненційний розподіл часу до відмови, то попереднє використання пристрою ніяким чином не впливає на послідуючий час його роботи. Тобто, якщо пристрій ще не відмовив до моменту часу $t$, то розподіл часу його безвідмовної роботи буде таким же, нібито в цей момент часу почав використовуватись абсолютно новий пристрій. Це, безумовно, протирічить багатьом природнім уявленням. Експоненційний розподіл є єдиним розподілом, який має подібну властивість [4, с. $41 ; 5$, с. 52...54].

$$
\text { Для прикладу використання }
$$

експоненційного розподілу, уявимо, що процес, який досліджується (наприклад, некерований процес коливання стулок повітрозабірника літака типу МиГ-29) має пікові викиди, та що саме ці різкі зміни зовнішніх умов можуть вплинути на стан пристрою, який розглядається, тобто пристрій може відмовити (руйнування елементів кріплення стулок повітрозабірника літака типу МиГ-29) лише в момент указаного пікового викиду. Якщо потік викидів є пуассонівським, то розподіл відмов даного пристрою $\epsilon$ експоненційним, і в цих умовах дійсно попереднє використання пристрою не відобразиться на подальшій тривалості безвідмовної роботи [3, с. 151].

Однак зрозуміло, що зазначена властивість експоненційного розподілу не дозволяє його використовувати для описання пристроїв, які в 
процесі нормальної експлуатації знаходяться під впливом факторів, що негативним чином відображаються на тривалості їх безвідмовної роботи [3, с. 171].

Виключенням 3 цього правила $є$ складні системи, елементи яких відновлюються в процесі експлуатації (функціонування). Для таких систем розподіл часу між відмовами може бути прийнято наближено експоненційним. $\mathrm{y} \quad\left[\begin{array}{lll}6, & \text { c. } & 63\end{array}\right]$ наводяться дослідження даних про відмови широкого класу елементів.

4. Розподіл Вейбулла.

Розподіл Вейбулла характеризує зростаючу інтенсивність відмов при $m>1$, де $m$ - змінний параметр, що має різні значення для окремих типів виробів (підбирається за результатом обробки експериментальних даних). Цей розподіл названо асиметричним розподілом третього типу для екстремальних значень [7, с. 121..123].

Для безперервної випадкової величини $\boldsymbol{t}$ (час напрацювання) щільність розподілу за Вейбуллом виражається формулою

$$
f(t)=\frac{m}{t_{0}} t^{m-1} e^{-\frac{t_{m}}{t_{0}}},
$$

де $m$ - змінній параметр, який має різні значення для окремих типів виробів (підбирається в результаті обробки експериментальних даних). Принаймні, якщо $m=1$, маємо експоненційний розподіл: при $m<1$ зі зростанням $\boldsymbol{t}$ величина $\lambda(t)$ зменшується; при $m>1$ зі зростанням $t$ величина $\lambda(t)$ збільшується; $t_{0}$ - параметр, що зв'язаний 3 середнім напрацюванням до відмови рівнянням:

$$
t_{c p}=b_{m} \frac{1}{t_{0}^{m}} \text { або } t_{o}=\left(\frac{t_{c p}}{b_{m}}\right)^{m},
$$

де $b_{m}=\Gamma\left(1+\frac{1}{m}\right)$.

Враховуючи вищезазначене розподіл Вейбулла доцільно використовувати для описання втомлювальних відмов, відмов вакуумних приладів (сильфонних вузлів агрегатів систем літаків, чутливих елементів агрегатів паливної автоматики авіаційних двигунів) та підшипників [8, с. 91; 9, с. 54; 10, с. 121].

5. Нормальний розподіл (нормальний закон розподілу Гаусса).

Основною особливістю нормального розподілу є те, що він $є$ граничним розподілом, до якого наближаються інші закони розподілу.

Сума достатньо великого числа незалежних (або слабо залежних) випадкових величин, що характеризуються різними законами розподілу, наближено підпорядковуються нормальному закону розподілу, причому тим точніше, чим більша кількість випадкових величин підсумовується.

Основне обмеження, що накладається на підсумовування випадкових величин, полягає в тому, щоб всі величини в загальній сумі мали відносно мале значення (до таких випадкових величин відносяться, наприклад, похибки вимірювань, помилки методичного порядку тощо). Якщо ця умова не виконується, та одне 3 випадкових значень різко перевищує в сумі всі інші, то це негативним чином впливає на ступінь коректності застосування даного закону розподілу.

На відміну від експоненційного розподілу та розподілу Вейбулла, що використовуються тільки для позитивних безперервних випадкових величин, нормальний розподіл може використовуватись для безперервних випадкових величин, які можуть приймати як позитивні, так i негативні значення від $-\infty$ до $+\infty$.

Щільність нормального розподілу визначається формулою:

$$
f(x)=\frac{1}{\sigma_{x} \sqrt{2 \pi}} e^{-\frac{\left(x-m_{x}\right)^{2}}{2 \sigma_{x}^{2}}} .
$$

Для оцінки розподілу тривалості строку служби (часу напрацювання до відмови) нормальний закон в чистому виді зазвичай не використовується. Розподіл часу напрацювання може бути тільки спрощеним нормальним, що формується 3 нормального шляхом обмеження інтервалу змінювання цієї величини.

Використання того чи іншого закону обумовлено характеристиками прояву та змін відмов виробів АТ у часі. Для більшості механічних, гідравлічних та електричних пристроїв (механізмів, блоків) практично неможливо виділити тільки раптові або тільки поступові відмови. Зустрічаються різноманітні поєднання обох типів відмов стосовно кожного конкретного виробу. Шляхом аналізу статистичних даних доводиться оцінювати їх відповідність теоретичному закону розподілу відмов. При цьому необхідно зазначити, що використання для авіаційних виробів експоненційного закону розподілу, який характеризує раптові відмови, потребує спеціального обгрунтування та може бути допущено для порівняно коротких проміжків часу експлуатації зразків АТ в міжремонтний період. 
Зважаючи на вищезазначене, пропонується для розгляду один 3 варіантів методичного підходу до визначення основних показників надійності зразків авіаційної техніки парку ЗС України, які експлуатуються за межами попередньо встановлених ресурсних показників.

Так, на початковому етапі визначення ймовірнісних властивостей надійності парку однотипних виробів АТ, що експлуатуються за межами попередньо встановлених ресурсних показників, необхідно опрацювати відповідні статистичні дані при визначенні законів розподілу напрацювання виробів (агрегатів) до відмови. Основою цього є результати виконання попереднього аналізу сучасного стану парку авіації ЗС України (за типами) 3 детальним опрацюванням причини виникнення відмови АТ для кожного конкретного випадку.

При дослідженні статистичних даних щодо надійності виробів (об'єктів), які не відновлюються на першому етапі мають бути сформовані наступні вихідні дані:

1. Тривалість експлуатації після крайнього ремонту виробу $\mathrm{AT}-t_{a}$.

2. Загальна кількість однотипних виробів АТ, які проходять контроль - $N$.

3. Число виробів АТ, які відмовили в процесі гарантійного обслуговування після ремонту на АРП $-m$.

4. Час напрацювання окремих виробів до відмови $-T_{1}, T_{2}, T_{i}, \ldots, T_{m}$.

На наступному етапі необхідно визначити закон розподілу відмов. Алгоритм дій при цьому наступний:

1. Отримані попередньо вихідні дані щодо показників напрацювання окремих виробів до відмови $T_{1}, T_{2}, T_{i}, \ldots, T_{m}$ розміщуються в ряд у порядку їх зростання (будується варіаційний ряд).

2. Загальний час післяремонтної експлуатації $t_{a}$ розбивається на $z$ інтервалів $\Delta t$ із таким розрахунком, щоб у кожний інтервал попало не менше двох значень $T_{i}$, тобто в кожному інтервалі було б не менше двох виробів (зразків АТ), що відмовили.

3. На основі сформованої розбивки складається таблиця з числом колонок $z$, в яку заносяться вихідні дані та результати розрахункового визначення статистичних даних:

$$
\hat{f}_{i}(t), \hat{\lambda}_{i}(t) \text { та } \hat{P}_{i}(t) .
$$

\section{4. Будуються графіки-гістограми $\hat{f}_{i}(t)$,} $\hat{\lambda}_{i}(t), \hat{P}_{i}(t)$ та на основі аналізу характеру їх динаміки змін формується припущення про відповідність отриманого статистичного розподілу одному 3 опробуваних теоретичних розподілів. Наприклад, за характером протікання графіків $\quad \hat{\lambda}_{i}(t)$ можливо порівнювати відповідність статистичного розподілу теоретичному:

- експоненційному, якщо величина $\hat{\lambda}_{i}(t)$ практично незмінна або мало змінюється за часом;

- розподілу Вейбулла, якщо $\hat{\lambda}_{i}(t)$ має зростаючу або регресну динаміку;

- нормальному, якщо спостерігається характерний мінімум у середній частині розподілу.

На підставі сформованих статистичних даних визначаються параметри випадкових величин вибраного теоретичного закону розподілу (математичної моделі) показників надійності. Наприклад, параметр $T$ для експоненційного, $m_{i}$ та $\sigma_{i}$ - для нормального, $m$ та $t_{0}$ - для розподілу Вейбулла.

5. Визначаються $f(t), \lambda(t), q(t)$ - ймовірнісні характеристики для всіх інтервалів $z$.

Для розрахунку експоненційного розподілу використовуються формули:

$$
\begin{gathered}
f_{i}(t)=\frac{1}{T} e^{\frac{-t_{i}+1}{T}} ; \quad \lambda_{i}(t)=\frac{1}{T} ; \\
q_{i}(t)=\int_{t_{i}}^{t_{i}+1} \frac{1}{T} e^{\frac{-t_{i}+1}{T}} .
\end{gathered}
$$

Для розподілу Вейбулла:

$$
\begin{gathered}
f_{i}(t)=\frac{m}{t_{0}} t_{i}^{m+1} e^{\frac{-t^{m}}{t}} ; \quad \lambda_{i}(t)=\frac{m}{t_{0}} t_{i}^{m-1} ; \\
q_{i}(t)=\int_{t_{i}}^{t_{i+1}} \frac{m}{t_{0}} t_{i}^{m-1} e^{\frac{-t^{m}}{t_{0}}} .
\end{gathered}
$$

6. Здійснюється порівняння статистичного та теоретичного розподілів показників надійності за допомогою одного 3 критеріїв узгодженості. Зазвичай використовується критерій $\chi^{2}$.

7. За допомогою знайденого сумарного значення $\chi^{2}$ та числа ступенів свободи $K$ визначається величина $P$ (для порівняльної оцінки необхідно брати величину $P_{z}=1-P$. Число ступенів свободи $K$ визначається 3 рівняння $K=z+1-s$, де $s-$ число зв'язків, які залежать від закону розподілу. Відповідність статистичного закону теоретичному оцінюється за величиною $P_{z}$. Якщо $P_{z}$ менше, ніж 0,1 , то необхідно підібрати інший закон розподілу, а 
саме такий, що більш підходить для опису статистичних даних.

У разі формування математичної моделі визначення ймовірнісних властивостей процесу гарантійного обслуговування зразків АТ, які експлуатуються за межами попередньо встановлених ресурсних показників на основі розподілу “ $\chi$-квадрат” треба мати на увазі, що цей розподіл використовується в теорії надійності для визначення довірчих меж при оцінці ймовірнісних характеристик та відповідності результатів, що отримані за допомогою теоретичних законів (моделювання) результатам, які отримані шляхом аналізу статистичних даних.

Розподіл “ $\chi$-квадрат” може бути визначений як сума квадратів незалежних нормальних величин із нульовим середнім значенням та одиничним відхиленням, тобто при $M(x)=0$ та $\sigma_{x}=1$

$$
x^{2}=\sum_{i=1}^{n}\left(\frac{x_{i}-a}{\sigma}\right)^{2} \text {. }
$$

Значення “ $x^{2}$ ”, у той же час, $є$ функцією об'єму вибірки числа $n$ виробів АТ, які досліджуються, з усього парку $N$ виробів АТ.

Для розподілу “ $\chi$-квадрат” введено параметр $K$, що називається числом ступенів свободи. Число ступенів свободи $K \in$ функцією числа складових елементів або вузлів виробу АТ, кількості польотів (нальоту після ремонту).

“ $\gamma$-квадрат" $є$ одним із різновидів розподілу “ $\chi$ - квадрат” при умові, що $K=2 m$.

“ $\gamma$-розподіл" та розподіл Пуассона зазвичай розглядаються у взаємозв'язку, тому що вони характеризують еквівалентні процеси. В якості змінної в “ $\gamma$ - розподілі” розглядається час, а в розподілі Пуассона - відмови.

В таблиці 1 наведені директивні характеристики для основних законів розподілу випадкових величин, що характеризують ймовірнісні властивості процесу гарантійного обслуговування зразків АТ, які експлуатуються за межами попередньо встановлених ресурсних показників.

Таблиця 1

Директивні характеристики для основних законів розподілу випадкових величин

\begin{tabular}{|c|c|c|c|c|}
\hline $\begin{array}{l}\text { № } \\
3 / \Pi\end{array}$ & Закон розподілу & $\begin{array}{c}\text { Математичне } \\
\text { очікування }\end{array}$ & Дисперсія & Коефіцієнт варіації \\
\hline 1 & Біноміальний & $n, q$ & $n, q, P$ & $\sqrt{P} / n q$ \\
\hline 2 & Пуассона & $n q$ & $n q$ & \\
\hline 3 & Експоненційний & $1 / \lambda$ & $1 / \lambda^{2}$ & 1 \\
\hline 4 & Вейбулла & $t_{o}^{1 / m} \Gamma(1 / m+1)$ & $t_{o}^{2 / m}\left[\Gamma\left(\frac{2}{m}+1\right)-\Gamma^{2}\left(\frac{1}{m}+1\right)\right]$ & $\frac{\sqrt{\Gamma\left(\frac{2}{m}+1\right)-\Gamma^{2}\left(\frac{1}{m}+1\right)}}{\Gamma\left(\frac{1}{m}+1\right)}$ \\
\hline 5 & Нормальний & $m_{x}$ & $\sigma_{x}^{2}$ & $\frac{\sigma_{x}}{m_{x}}$ \\
\hline 6 & $\begin{array}{c}\text { Розподіл } \\
\text { “ } \chi-\text { квадрат” }\end{array}$ & $K$ & $2 K$ & $\sqrt{\frac{2}{K}}$ \\
\hline 7 & “ $\gamma$ - розподіл” & $m C$ & $m C^{2}$ & $\frac{1}{\sqrt{m}}$ \\
\hline
\end{tabular}

Джерело: розроблено авторами за даними [3, 4].

При виборі необхідної математичної моделі зі всіх тих, що запропоновані вище, доцільно попередньо визначити закони розподілу відмов тих елементів зразків авіаційної техніки, відмова яких несе найбільші ризики при підтриманні необхідного рівня справності парку відповідного типу АТ.

Враховуючи те, що заміна (ремонт) зазначених елементів не передбачена нормативно- технічною (ремонтною) документацією АРП, підприємство не несе юридичної відповідальності за негативні наслідки цього в процесі гарантійного обслуговування.

Додаткова заміна цих елементів за наробітком може бути доцільною, якщо середній час до появи неочікуваної відмови в процесі функціонування зразка авіаційної техніки є функцією, що убуває. 


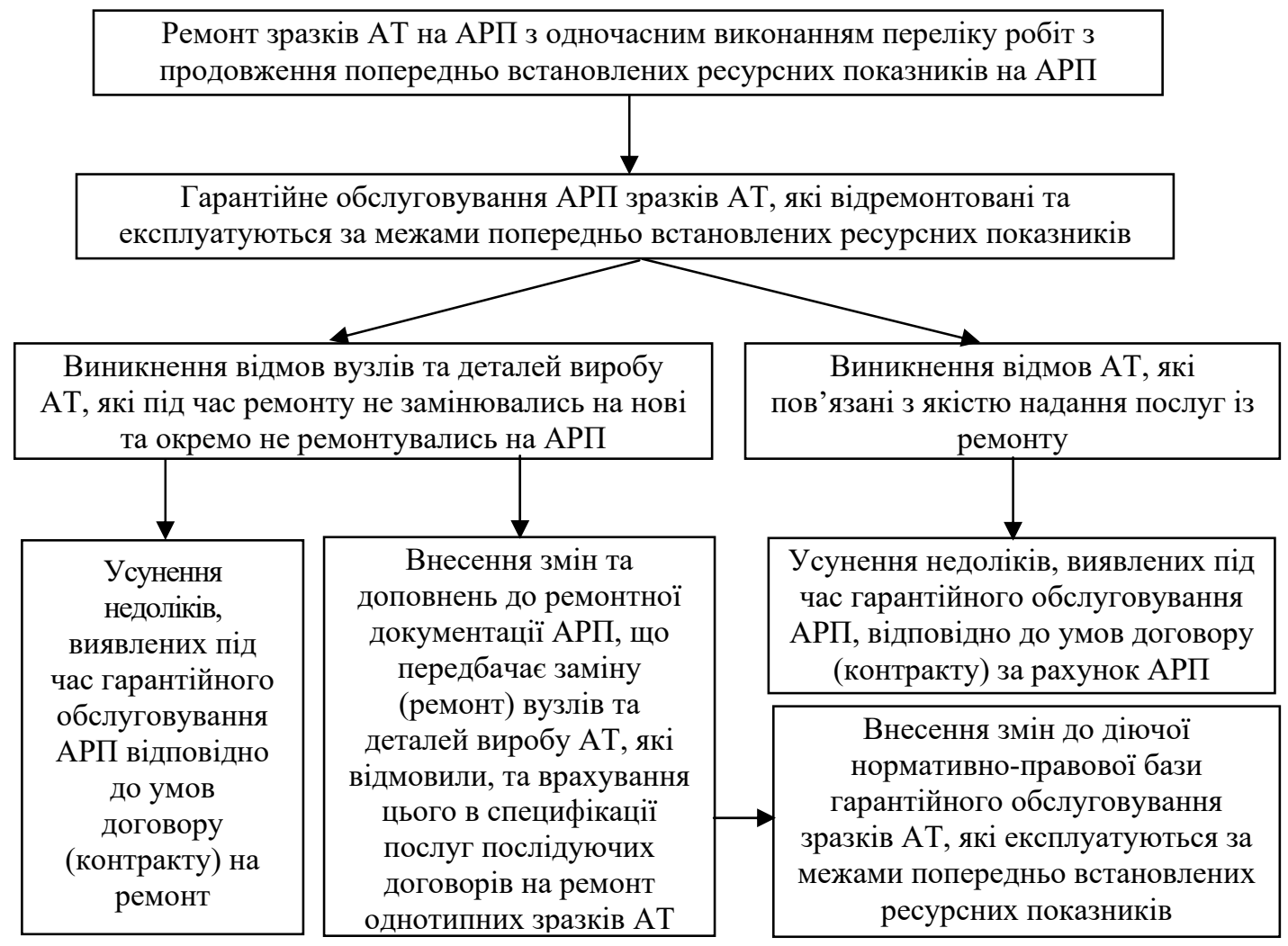

Рис. 1. Алгоритм процесу гарантійного обслуговування відремонтованих зразків АТ, які експлуатуються за межами попередньо встановлених ресурсних показників.

Джерело: розроблено авторами.

Також при цьому слід враховувати середне значення залишкового часу безвідмовної роботи цього елемента. Якщо умовне математичне очікування часу безвідмовної роботи елемента, що характеризується напрацюванням (строком служби), убуває зі зростанням часу, то здійснення попереджувальної заміни (ремонту) є доцільним [3, с. 41...47]. Додаткові витрати на заміну (ремонт) зазначених елементів, які розраховуються 3 урахуванням втрат часу, матеріальних та людських ресурсів, повинні бути при цьому не більші, ніж отримана раніше економія.

Алгоритм процесу гарантійного обслуговування відремонтованих на АРП зразків AT, які експлуатуються за межами попередньо встановлених ресурсних показників, наведено на рис. 1. Внесення змін та доповнень до ремонтної (технологічної) документації АРП, що передбачає заміну (ремонт) агрегатів, вузлів та деталей виробу АТ, які відмовили в період гарантійного обслуговування зразка АТ, має здійснюватися згідно вимог діючих нормативних документів 3 урахуванням [11, с. $101 ; 12$, с. 145$]$.

На заключному етапі процесу розробки методичного підходу має бути проведена його апробація, а саме визначення ймовірнісних властивостей процесу гарантійного обслуговування конкретного зразка АТ, що експлуатуються за межами попередньо встановлених ресурсних показників, порівняння отриманих результатів 3 достовірними характерними розподілами.

На практиці, при виконанні робіт щодо аналізу надійності зразків АТ, у більшості випадків доводиться мати справу зі складними агрегатами, що включають у себе різноманітні складові елементи.

Наприклад, насос підкачки палива складається 3 двох принципово різних за конструкцією частин: електродвигуна та нагнітаючого вузла-насоса. Електродвигун, який, в свою чергу, складається 3 ротора, статора та щіткового пристрою, може відмовляти через перевищення напруги струму, порушення електроізоляції, перегріву, зношення щіток тощо. Причинами несправностей нагнітаючої частини можуть бути порушення герметичності ущільнень, завищена насиченість палива парогазовими включеннями, збільшення температури палива на вході в насос, недостатні змащувальні властивості палива тощо, тобто 
можливі різноманітні фізичні причини відмов окремих елементів.

Звісно, різним типам відмов притаманні свої специфічні закони розподілу. Наприклад, експоненційному закону розподілу підпорядковуються, в основному, випадкові раптові відмови виробів АТ.

\section{Висновки}

Таким чином, використання запропонованих в статті математичних моделей та методичного підходу до визначення ймовірнісних властивостей процесу гарантійного обслуговування зразків АТ, які експлуатуються за межами попередньо встановлених ресурсних показників, дають можливість в певній мірі упередити виникнення відмов, які не пов'язані з проведенням ремонту на АРП, а є наслідком конструктивних недоліків, та тривалого терміну експлуатації.

Подальші дослідження авторів буде зосереджено на визначенні ймовірнісних властивостей процесу гарантійного обслуговування зразків авіаційної техніки і аналізу відповідних параметрів.

Результати апробації розробленого й запропонованого авторами статті методичного апарату буде представлено у подальших наукових статтях.

\section{Список літератури}

1. Сушак М.Б., Борохвостов В.К., Рябець О.М. Оцінка ефективності та проблемні фінансові, економічні та виробничо-технологічні питання впровадження на підприємствах України імпортозаміщення під час заводського ремонту авіаційної техніки // Озброєння та військова техніка, 2016. - № 3. - С. 8-13.

2. Сушак М.Б., Масягін В.І. Забезпечення надійності деталей авіаційних двигунів, налагодження виготовлення яких здійснюєтся за директивними процесами // Збірник наукових праць Харківського національного університету Повітряних Сил імені Івана Кожедуба, 2018. - № 4 (58). - С. 71-79.

3. Косточкин В.В. Надежность авиационных двигателей и силовых установок. - М., Машиностроение, 1988. - 272 с.

4. Р.Барлоу, Ф.Прошан. Математическая теория надежности. Пер. с англ. под ред. Б.В. Гнеденко. - М.: Изд-во “Советское радио”, 1969. - 488 с.

5. Feller W. An Introduction to Probability Theory and Its Applications, v.1, 2 nd ed. John Wiley and Sons. New York, 1957. - Pp. 90-112.

6. Dais D.J. An Analysis of failure data, J. Amer. Statist. Assoc., v. 47. 1952. - №258. - Pp. 113-150.

7. Gumbel E.J. Statistics of Extremes, Columbia University Press, New York, 1958. - Pp. 71-73.

8. Weibull W. A statistical theory of the strength of materials. Ing. Vetenskaps Akad. Handl, 1939. - №151. - Pp. 62-63.

9. Kao J.H.K. Computer methods for estimating Weibull parameters in reliability studies, IRE Transactions on Reliability and Quality Control, 1958. - PGRQC-13. - Pp. 15-22.

10. Leiblein J. and Zelen M. Statistical investigation of the fatigue life of deep-groove ball bearings, J. Res., Nat. Bureau Stand., 1956. - v. 57. - Pp. 273-316.

11. Мышкин Л.В. Прогнозирование развития авиационной техники: теория и практика. - М.: Физматлит, 2008. $-328 \mathrm{c}$.

12. Саати Т. Принятие решений при зависимостях и обратных связях: Аналитические сети. - М.: Изд-во ЛКИ, 2008. $-360 \mathrm{c}$

\section{Відомості про авторів:}

\section{Сушак Михайло Борисович}

кандидат технічних наук старший науковий співробітник

начальник науково-дослідної лабораторії

Державного науково-дослідного інституту авіації, Київ, Україна

https://orcid.org/0000-0001-7747-2303

\section{Грень Віталій Миколайович}

старший науковий співробітник

Державного науково-дослідного інституту авіації,

Київ, Україна

https://orcid.org/0000-0001-8920-2351

\section{Information about the authors:}

\author{
Mykhailo Syshak \\ Candidate of Technical Sciences \\ Senior Researcher \\ Head of Research Laboratory \\ of State Research Institute of Aviation, \\ Kyiv, Ukraine \\ https://orcid.org/0000-0001-7747-2303

\section{Vitalii Gren} \\ Senior Researcher \\ of State Research Institute of Aviation, \\ Kyiv, Ukraine \\ https://orcid.org/0000-0001-8920-2351
}




\section{Клобукова Ніна Володимірівна}

науковий співробітник

Державного науково-дослідного інституту авіації, Київ, Україна

https://orcid.org/0000-0002-4538-5616

\section{Чернозубкін Ігор Олександрович}

кандидат технічних наук

доцент

провідний науковий співробітник

Центрального науково - дослідного інституту

Збройних Сил України,

Київ, Україна

https://orcid.org/0000-0002-3243-4714

\section{Nina Klobukova}

Researcher Associate

of State Research Institute of Aviation, Kyiv, Ukraine

https://orcid.org/0000-0002-4538-5616

\section{Igor Chernozubkin}

Candidate of Technical Sciences

Associate Professor

Leading Researcher

of Central Research Institute

of the Armed Forces of Ukraine,

Kyiv, Ukraine

https://orcid.org/0000-0002-3243-4714

\title{
METHODICAL APPROACH TO DETERMINATION OF THE MAIN INDICATORS OF RELIABILITY OF SAMPLES OF AVIATION EQUIPMENT IN THE INTERPAIR PERIOD OF OPERATION
}

\author{
M. Sychak, V. Gren, N. Klobukova, I. Chernozubkin
}

The article presents the results of research and analysis of the problems of ensuring a given level of serviceability of the fleet of military aircraft in the maintenance period showed that the technical condition of the entire fleet of aircraft of the Air Force of the Armed Forces of Ukraine is characterized by exhaustion of established indicators (service life and resource), its components and components. Restoration of a serviceable condition of aviation equipment according to the operating method of operation "on a resource" is possible only by performance of capital (average) repair.

The laws of distribution of failures that occur on samples of aircraft of the Air Force of the Armed Forces of Ukraine in the post-repair period are random variables, are of great importance for the theory and practice of work to ensure the reliability of products. Knowledge of these laws allows you to calculate and predict the reliability of products at the stages of their warranty service. This is important when assessing the feasibility of installing and extending the life of aircraft products to the limit level, because it depends on the safety of aircraft.

In complex aviation products, the laws of distribution of failures and malfunctions are a combination (composition) of different distributions, which are inherent in the individual elements of these products. Most of them, in the process of repair at the aircraft repair plant, are increasing resource indicators to ensure the service life of aircraft in general.

Keywords: repair, warranty service, exploitation, reliability, resource indexes. 